\title{
Öğretmenlerin Bireysel Hesap Verebilirlik Eğilimlerinin Bireysel ve Kurumsal Bağlam Özellikleri Açısından Karşılaştırılması
}

\author{
DOI: $10.26466 /$ opus.613111
}

\author{
* \\ Coşkun Erdağ \\ ** Dr. Öğr. Üyesi, Aksaray Üniversitesi, Eğitim Fakültesi, Aksaray / Türkiye \\ E-Posta: coskunerdag79@gmail.com \\ ORCID: $\underline{0000-0002-6173-6340}$
}

Öz

Bu çalışma, Türkiye'de öğretmenlerin hesap verebilirliklerine ilişkin eğilimlerini betimlemeyi ve bu eğilimlerin bireysel ve kurumsal özelliklere göre farklılaşma düzeylerini belirlemeyi amaçlamaktadır. Aksaray merkez ilçe sinırları içinde görev yapan ilk, orta ve lise okullarında görevli öğretmenlerden rastgele belirlenen örneklem grubuna 'Öğretmenlerin Bireysel Hesap Verebilirlikleri Ölçeği' uyarlanmış, uygulama sonrası elde edilen ölçek puanları önce betimlenmiş, arkasından da cinsiyet, kıdem, eğitim düzeyi, branş, yerleşim yeri, okul türü, sınıf mevcudu gibi bireysel ve kurumsal faktörlere göre fark analizleri yapılmıştır. Çalışma sonucunda, öğretmenlerin dış paydaşların beklentilerini karşılama, bunun sonucunda ödül elde etme veya mevcut yaptırımlardan kurtulma eğilimlerinin orta düzeyde olduğu, buna karşın, meslek etiğine uygun davranma, yeni şeyler öğrenme ve bu sayede kendini geliştirme ile en etkili ve doğru davranışı gösterme eğilimlerinin ise daha güçlü oldŭ̆u görülmüştür. Yerleşim yeri, sınıf mevcudu, branş, eğitim düzeyi ve kıdemden farkl olarak, öğretmenlerin hesap verebilirlik eğilimlerinin cinsiyetleri ve görev yapılan okul türüne göre farklılaştığı tespit edilmiştir. Erkek öğretmenler bayanlara kıyasla daha çok dış performans değerlendirmelerine uygun davranarak belirlenen ödüllere ulaşma ve yaptırımlardan kurtulma eğilimi gösterirken, Anadolu liselerinde çalı̧an öğretmenler ise diğerlerine kıyasla daha çok meslek etiğine uygun davranmayı, mesleki yeterlik ve gelişimlerini sağlama eğiliminde oldukları tespit edilmiş̧ir.

Anahtar Kelimeler: Öğretmen hesap verebilirliği, içsel hesap verebilirlik, dışsal hesap verebilirlik, Cinsiyet, Okul Türü 


\title{
Exploring Individual and Institutional Factors Affecting Teacher Personal Accountability Felt
}

\begin{abstract}
This study aims to describe Turkish teachers' dispositions of accountability and to determine the individual and institutional factors that affect their accountability dispositions. Data were collected through the Teacher Personal Accountability Scale from the random sample of teachers working at K-12 schools in Aksaray. Teacher personal accountability score distributions were first described, and then analyzed based on the individual and institutional factors such as gender, experience, education level, teaching branch, school location, type of schooland class size. Found that teachers in Turkey do feel rather more internally accountable with respect to their teaching than feel externally accountable in their interactions with senior management units. They are neither strongly reactive nor supportive to be rewarded or sanctioned according to the standards-based student evaluations. On the other hand, they strongly feel internal accountability and more tuned to behave in accordance with the professional ethics in teaching, to ensure their professional competence and professional development. Gender emerges as a factor for teacher external accountability whereas school type for internal accountability.
\end{abstract}

Keywords: Teacher accountability, External accountability, Internal accountability, Gender, School type 


\section{Giriş}

İnsanın olduğu tüm sistemlerin verimliliği ve etkililiğine ilişkin tartışmalarda hesap verebilirlik olgusuna büyük önem atfedilmektedir (Frink ve Klimoski, 1998; Lerner ve Tetlock, 1999; Tetlock, 1985; Hochwarter, Perrewé, Hall ve Ferris, 2005). Dünya genelinde sosyal bir sistem olarak hem eğitim hem de okul sistemlerinin etkililiğinin sağlanması en temel sorunlardan biri olarak görülmüş, bu amaçla okul, öğretmen, okul yöneticisi veya öğrenciyi merkeze alan farklı hesap verebilirlik politikaları kurgulanmış ve uygulamaya konulmuştur. Günümüz hesap verebilirlik uygulamalarında daha çok yasa, bürokrasi, piyasa ve profesyonel kaynaklardan okul üzerinde oluşturulan akademik performans beklentilerine okulların cevap verebilmeleri, gerekli mekanizmaları üretip işlerlik kazandırmaları, öğrenci kazanımlarını geliştirmeleri beklenmektedir. Temel amaç, öğretmen davranışlarını daha etkili ve verimli hale dönüştürmek, böylece okul sonuçlarının, özellikle de öğrencilerin akademik kazanımlarının geliştirilmesini sağlamaktır. Bu bağlamda hesap verebilirlik, hem öğretmenler üzerinde dışarıdan yaratılan bir performans baskısı, hem de öğretmenlerin motivasyon ve öğretim kapasitelerini desteklemeye yönelik içsel mekanizmalar olarak ele alınmaktadır.

Formal olarak kurgulanan veya informal olarak oluşan okul hesap verebilirlik ortamının öğretmenler üzerinde nasıl sonuçlar ürettiğine ilişkin yapılan araştırmalarda ise, öğretmenlerin ne kadar hesap verebilir oldukları daha çok öğretmenlerin ortaya koyduğu performans artışı veya üstlerinin geri bildirimleri üzerinden tahmin edilmeye çalışılmıştır (Frink ve Klimoski, 1998). Rosenblatt (2017) bu çalışmalarda öğretmenlerin hesap verebilirliğinin daha çok nesnel gerçeklik üzerinden ölçüldüğü, fakat öğretmenlerin öznel gerçekliğinin ise hiç hesaba katılmadığını ileri sürmektedir. Diğer bir deyişle, bu nesnel ölçümlerin öğretmenlerin görevlerine ilişkin hesap vermeye ne kadar meyilli oldukların göstermediğini, öğretmenlerin sahip oldukları hesap verme duygusunu tam olarak temsil etmediğini iddia etmektedir. Rosenblatt (2017) bireylerin hesap verebilirliğine ilişkin alandaki bu boşluğu örgütsel yaşamda çalışanların hissettikleri hesap verebilirlik duyguları üzerine yapılan sınırlı sayıdaki çalışmayı temel alarak (e.g. Hochwarter et al., 2005; Roch ve McNall, 2007), öğretmen hesap verebilirliğini öznel bir gerçeklik olarak ele almış ve gösterge davranışlarını belirlemiştir. Rosenblatt (2017), öğretmen he- 
sap verebilirliğini sadece dış talep ve beklentilere uyum gösterme çabası olarak değil, aynı zamanda öğretmenlerin sahip oldukları mesleki yeterlik ve mesleki gelişim ihtiyac ile mesleki etik değerleri de içeren iki boyutlu öznel bir gerçeklik olarak kavramlaştırmıştır. Böyle bir yaklaşım ise önemlidir, çünkü çalışanların hesap verebilirlik duygularının onların iyi oluşları, motivasyonları ve performansları üzerine etkili olduğu yönünde çalışmalar bulunmaktadır (Cheng ve Tsui, 1999; Frink ve Ferris, 1998; Hall, Frink, Ferris, Hochwarter, Kacmar ve Bowen, 2003). Bu açıdan bakıldığında, öğretmenlerin hesap verebilirlik eğilimlerinin Türkiye bağlamında anlaşılması, açıklanması ve sonuçlarının tahmin edilmesi hem öğretmenlerin hem de okulların etkililiği ve sağlığı için büyük önem arz etmektedir. Hem ulusal hem de uluslararası alanyazına bakıldığında, öğretmenlerin hesap verebilirlik eğilimlerine ilişkin çalışmaların daha çok öğretmenlerin cevap verebilirliklerine odaklandığı, ve öğretmenlerin hesap verebilirliklerine ilişkin öznel duygularını ortaya koymadığı görülmektedir. Bu çalışmalarda kimin, kime, hangi konularda nasıl hesap vermesi gerektiği ve hesap verebilirlik uygulamalarının öğretmenler üzerindeki etkileri, ve öğretmen ve okul yöneticilerinin bu mekanizmalara nasıl tepki verdiği üzerine yoğunlaşılmıştır (Bülbül, 2011; Çiçekli, 2016; Erdağ, 2017; Erdağ ve Karadağ, 2018; Erkoşar, 2013; Kantos, 2010; Kardaş, 2019; Küçükaycan, 2018; Özen, 2011; Özcan, 2011; Bakioğlu ve Salduz, 2014; Too, 1989; Türkoğlu, 2015; Yıldırım ve Yenipınar, 2019; Yi ve Kim, 2019). Öğretmenlerin hesap verebilirliklerini nasıl anlamlandırdıkları ve içinde bulundukları bağlamların hesap verebilirlik anlayışlarını nasıl etkilediği konularında çalışmaların ise eksik olduğu anlaşılmaktadır. Buradan hareketle, bu çalışma öğretmenlerin hesap verebilirlik anlayışlarını betimlemeyi, bazı bireysel ve kurumsal faktörlerin öğretmenlerin hesap verebilirlik duygularını nasıl belirlediğini açıklamayı amaçlamaktadır. Bu kapsamda, (i) öğretmenlerin içsel ve dışsal hesap verebilirlik eğilimlerinin nasıl dağıldığı, (ii) öğretmenlerin içsel ve dışsal hesap verebilirliği ile bireysel hesap verebilirlik eğilimlerinin öğretmenlerin cinsiyet, branş, eğitim düzeyi, kıdem gibi bireysel özellikler ile okulların bulunduğu yerleşim yerleri, sını mevcudları ve okul türleri gibi kurumsal bağlam özelliklerine göre farklılaşıp farklılaşmadığı sorularına cevap aranmaktadır. 


\section{Bireysel Hesap Verebilirlik Bağlamında Öğretmen Hesap Verebilirliği Kavramı}

Literatür incelendiğinde, ahlaki bir kavram olarak öne çıkan hesap verebilirlik, kamu ve özel kurumların yönetim uygulamalarında hesap verme beklentisi, cevap verebilirlik, yükümlülük, şeffaflık kavramları ile eş anlamlı olarak kullanılmakta, daha çok uygun ve doğru davranışa odaklanarak birey ve kurumların aldıkları kararlara ve ortaya koydukları eylemlere ilişkin diğer birey ve kurumlara karşı olan sorumluluklarına odaklanmaktadır (Levitt, Janta ve Wegrich, 2008). Örgütsel yaşam bağlamında ele alındığında, hesap verebilirlik sosyal bir baskı olarak ele alınmakta, çalışanın başka biri tarafından değerlendirileceği ve bir gün eylemlerine ve aldığı kararlara ilişkin cevap verme, açıklama yapma, savunma yapma zorunda kalacağı algısı olarak kavramlaştırılmaktadır (Frink ve Ferris, 1998). Lerner ve Tetlock (1999) bireylerin hesap verebilirliklerini kişinin duygularını, inançlarını ve eylemlerini başkalarına haklı çıkarma yönündeki örtük veya açık eğilimler olarak ele almaktadır. Frink ve Klimoski (1998) ise, kendinden önceki bu ve diğer tanımları temel alarak psikolojik süreçleri daha çok hesaba katan yeni bir tanımlama yapmış, hesap verebilirliği ödül ve yaptırımların hesap verebilirlik koşullarına bağlı olarak algılandığı, ödül ve yaptırım gücüne sahip bazı dış gözlemcilere karşı eylem ve kararlarını savunma ve haklıı̆̆ı̆ı gösterme yönünde hissedilen ihtiyaç olarak ele almaktadır. Hall (2005) ise, tüm bu tanımlamalardan yola çıkarak hesap verebilirliğin tanımını kişinin kararlarının veya eylemlerinin, sonucuna dayalı ödüller veya yaptırımlar alma potansiyelinin var olduğu inancıyla, kendisi de dahil bazı öne çıkan izleyici odakları tarafından ileride değerlendirilmeye tabi olacağı yönündeki örtük veya açık bir beklenti olarak sentezlemiştir. Bu tanımlamalara göre, bireylerin hesap verebilirliğinden hem ast ile üst arasında kurulan sosyal bir ilişki, hem de ödül ve ceza beklentisi içerisinde olan astın bir üst tarafından davranışlarının değerlendirmesi süreci anlaşılmaktadır. Bu bağlamda, hesap verebilirlik (i) değerlendirme beklentisi, (ii) astın izlenmesi, (iii) asttan belirli karar ve eylemlere ilişkin bilgi istenmesi, (iv) astın üstün standartlarına yada beklentilerine göre yargılanması, (v) dönüt verilmesi, (vi) astın ödüllendirilmesi veya yaptırıma maruz bırakılması öğelerinden oluşmaktadır (De Dreu ve Van Knippenberg, 2005; Frink, 
Hall, Perryman, Ranft, Hochwarter, Ferris ve Royle, 2008; Frink ve Klimoski, 2004; Hall ve Ferris, 2011; Hall, Frink ve Buckley, 2017, Lerner ve Tetlock, 2003; Mitchell, 1993; Rosenblatt, 2017; Scholten, van Knippenberg, Nijstad, ve De Dreu, 2007). Kurulan bu sosyal ilişkide, astı belirli bir standarda ilişkin aldığı bilgi temelinde değerlendirerek kontrol altında tutan dış bir odak olabileceği gibi, astın kendisi de böyle bir kontrolü sağlayabilir. Firestone ve Shipps (2005) tarafından dışsal hesap verebilirlik olarak adlandırılan ilk mekanizmada meşru bir dış odak tarafından önceden üzerinde uzlaşlan standartlara uygun davranma konusunda ast üzerinde bir dış baskı üretilmektedir. Öğretmenler özelinde bakıldığında ise, işverenlerle yapılan sözleşmeler, uygulamadaki yasalar, denetimler ve kamuoyuyla paylaşılan öğrenci performans raporları ve okul kültürü ile formal veya informal şekilde öğretmenler üzerinde dış beklenti ve taleplere uygun davranma konusunda zorlayıcı bir baskı ortamı oluşturulmaktadır. Dış baskı kaynakları yöneticiler ve müfettişler gibi resmi unsurlar olabileceği gibi, veliler, öğrenciler, meslektaşlar gibi unsurlar da olabilir. İçsel hesap verebilirlik (Hochwarter et al. 2005; Schlenker ve Weigold, 1989; Firestone ve Shipps, 2005; Folger ve Cropanzano, 2001) olarak adlandırılan diğer bir mekanizmada ise, bireyin beklenti ve taleplere uygun bir şekilde davranış göstermesi yönündeki hesap verebilirlik baskısı bireyin kişisel değerleri ve ahlak ilkeleri kaynaklıdır. Bireyin duygu ve düşünce aleminde oluşan böyle bir içsel kontrol mekanizmasında birey hem ast hem de üst olarak rol oynamaktadır. Bireyin kendisi, hem göreve ilişkin belirli davranış standartlarını ve ulaşılması gereken hedefleri ortaya koyar, hem de standartlara uygunluk ve hedeflere ulaşmaya ilişkin kendisi bilgi toplar, ve buna göre kendi eylemlerini sübjektif olarak değerlendirir. İçsel hesap verebilirlik mekanizmasında birey üzerinde etki gösteren hesap verebilirlik baskısı mesleki yeterlilikler, gelişim ve mesleki etik ilkeler odaklı olabilir.

\section{Yöntem}

Bu araştırmada, öğretmenlerin bireysel hesap verebilirlik duygularını betimlemek ve sahip olunan hesap verebilirlik eğilimlerini bazı bireysel ve kurumsal faktörlere göre farklılaşma durumunu belirlemek amacıyla ilişkisel desen kullanılmıştır. 


\section{Evren ve Örneklem}

Araştırmanın evrenini, Aksaray ili merkez ilçesi sınırlarındaki eğitim kurumlarında görev yapan tüm öğretmenler oluşturmaktadır. Araştırmanın örneklemi rastgele yöntemle iki aşamada belirlenmiştir. İlk aşamada küme örnekleme yöntemi kullanılarak öğretmenleri görev yaptıkları okullar eğitim kademelerine göre kümelenmiştir. Bu işlemde okul kademeleri, türleri ve öğrenci mevcutları baz alınmıştır. İkinci aşamada, her okul kümesinden öğretmenler temsil sınır değerine ulaşıncaya kadar okul bazında rastgele yöntemle belirlenmiştir. Belirlenen okullarda görev yapan toplam 228 öğretmen örnekleme dahil edilmiştir. Örneklem gruplarının demografik özellikleri Tablo 1'de sunulmuştur.

\section{Veri Toplama Araçlar}

Çalışmada öğretmenlerin bireysel hesap verebilirlik duygularını ölçmek amaciyla Rosenblatt (2017) tarafından geliştirilen Öğretmenlerin Bireysel Hesap Verebilirlik Ĕ̆gilimleri Ölçeği kullanılmıştır. 13 maddeden oluşan ve öğretmen yanitlarını 1 "kesinlikle katılmıyorum" ile 5 "kesinlikle katılıyorum" arasında dereceleyen 5'li likert tipi bu ölçek iki faktörden oluşmaktadır. Rosenblatt (2017) ölçeği İsrail örnekleminde doğrulayıc faktör analiziyle test etmiş ve iki faktörlü yapısını doğrulamıştır $(\chi 2 / \mathrm{df}=2.51, \mathrm{p}<0.001, \mathrm{CFI}=0.93, \mathrm{RMSEA}=$ 0.071). Ölçeğin güvenirliği içsel tutarlık analiziyle değerlendirilmiş, dişsal hesap verebilirlik boyutu için Cronbach alfa .71, içsel hesap verebilirlik boyutu içinse .85 olarak rapor edilmiştir. İki faktörden ve 13 maddeden oluşan orjinal ölçek maddeleri önce çeviri-ters çeviri yöntemi kullanarak Türk kültürüne uyarlanmış, sonrasında ölçeğin Türkçe versiyonunun yapı geçerliliği test edilmiştir. Ölçeğin faktör yapısına ilişkin teorik modelin veriye uygunluğu güçlü şekilde doğrulanmamıştır $(\chi 2 / \mathrm{dF}=2.51$, CFI = 0.92, $\mathrm{SRMR}=.07$, RMSEA = 0.09). Yapılan Açımlayıcı Faktör Analizi'nde üç maddenin modelden çıkarılmasıyla ölçeğin faktör yapısı yeniden modellenmiş, madde ortak varyans değeri .35 'den büyük olan ve faktör yükleri .46 ile .93 arasında değişen iki faktörlü ve 10 maddeden oluşan ölçme modeli toplam varyansın \%68.21'ini açıklamıştır. Bu yeni modelin veriye uygunluğu yapılan Doğrulayıcı Faktör Analizi ile doğrulanmıştır $(\chi 2$ / dF = 2.37, CFI = 0.96, $\mathrm{SRMR}=.06, \mathrm{RMSEA}=0.07)$. Uyarlanan ölçeğin dışsal hesap verebilirlik 
boyutuna ait Cronbach alfa ve CR iç tutarlılık katsayıları 0.65 üstü, içsel hesap verebilirlik boyutu içinse 93 üstü olduğu görülmüştür.

Tablo 1. Örneklem Grubunun Demografik Özelliklerine İlişkin Dă̆ılımlar

\begin{tabular}{|c|c|c|c|c|c|c|c|c|}
\hline Seçenekler & & 1 & 2 & 3 & 4 & 5 & 6 & Toplam \\
\hline & & Erkek & Kadın & & & & & \\
\hline \multirow[t]{3}{*}{ Cinsiyet } & $N$ & 130 & 96 & & & & & 226 \\
\hline & $\%$ & 57.5 & 42.5 & & & & & 100 \\
\hline & & LGS/YKS & Okul D. & Ana/Sinıf & Diğer & & & \\
\hline \multirow[t]{3}{*}{ Branş } & & 151 & 30 & 26 & 19 & & & 226 \\
\hline & & 66.8 & 13.3 & 11.5 & 8.4 & & & 100 \\
\hline & & $1-5 y 11$ & 6-10yil & 11-15yıl & 16-20yil & $+21 \mathrm{y} 11$ & & \\
\hline \multirow[t]{3}{*}{ Kidem } & $N$ & 14 & 34 & 67 & 71 & 40 & & 226 \\
\hline & $\%$ & 5.7 & 13.9 & 27.5 & 29.1 & 16.4 & & 100 \\
\hline & & Lisans & Lisans üstü & & & & & \\
\hline \multirow[t]{3}{*}{ Eğitim Düzeyi } & $N$ & 169 & 57 & & & & & 226 \\
\hline & $\%$ & 74.8 & 25.2 & & & & & 100 \\
\hline & & İlçe/Köy & ìl & & & & & \\
\hline \multirow[t]{3}{*}{ Yerleşim } & $N$ & 60 & 166 & & & & & 226 \\
\hline & $\%$ & 26.5 & 73.5 & & & & & 100 \\
\hline & & 1-10 öğr. & 11-20 öğr. & 21-30 öğr. & $30+$ öğr. & & & \\
\hline \multirow[t]{2}{*}{ Sinif Mevcudu } & $N$ & 30 & 37 & 115 & 44 & & & 226 \\
\hline & $\%$ & 13.3 & 16.4 & 50.9 & 19.5 & & & 100 \\
\hline \multirow{3}{*}{ Okul Türü } & & Fen/Sos & Anad.L. & İHL & MeslekL. & Ortao. & Ana/İlk & \\
\hline & $N$ & 36 & 32 & 12 & 41 & 87 & 18 & 226 \\
\hline & $\%$ & 15.9 & 14.2 & 5.3 & 18.1 & 38.5 & 8.0 & 100 \\
\hline
\end{tabular}

\section{Isşlem}

Öğretmenlerin bireysel hesap verebilirliklerine ilişkin eğilimlerini bazı bireysel ve kurumsal faktörlere göre farklılaşma düzeyini belirlemek için yürütülen bu çalışmanın aşamaları şunlardır: (i) Hazırlanan anket aracılığıyla, katılımc öğretmenlerin demografik özellikleri (cinsiyet, okul tipi, okul kademesi, okul türü, branş, kıdem, yerleşim yeri) kaydedilmiş, aynı zamanda Öğretmenlerin Bireysel Hesap Verebilirlikleri Ölçeği'yle de dişsal ve içsel bireysel hesap verebilirlik eğilimleri 5'li likert ölçeğiyle derecelendirilmiştir. (ii) Analizlere hazırlık amacıyla yapılan ön incelemede, tüm katılımcı öğretmenlerin tüm sorulara cevap verdiği görülmüştür. İki katılımc ise samimi olmayan cevaplarından dolayı veri setinden çıkarılmıştır. Veri setinde hata kaynaklı yanlış veri girişine rastlanılmamıştır. (iii) Katılımcı öğretmenlerin dışsal hesap vere- 
bilirlik, içsel hesap verebilirlik ve bireysel hesap verebilirlik eğilimleri puanlarının demografik değişkenlerdeki her bir öğretmen alt grubu içerisindeki dağılımları frekans $(n)$, yüzde $(\%)$, aritmetik ortalama $(X)$ ve standart sapma (SS) değerleri ile betimlenmiştir. (iv) Demografik alt gruplara göre, öğretmenlerin dışsal ve içsel hesap verebilirlik eğilimleri alt ölçek puanları ortalamaları arasında anlamlı farklılıkların olup olmadığına ilişkin bağımsız örneklemler t-testi ve tek yönlü ANOVA analizlerine geçilmeden önce, alt ölçek puanlarının normal dağılım gösterip göstermediği çarpıklık katsayıları ve standart hataları değerlendirilerek belirlenmiştir. Dışsal hesap verebilirlik puanları normal dağılım gösterirken (Çarpıklık= 268 , Std.Hata=.162), içsel hesap verebilirlik puanları (Çarpıklık=-2.082, Std.Hata=.162). ve öğretmenlerin bireysel hesap verebilirlik puanları (Çarpıklık=-1.691, Std.Hata=.162) normal olmayan dağılım göstermiştir. Bunun üzerine içsel hesap verebilirlik ve öğretmenlerin bireysel hesap verebilirlik eğilimleri puanlarının log10 dönüşümleri yapılmış, ortalama karşılaştırma analizlerinde bu puanlar kullanılmıştır. Grup varyanslarının homejenliği ise Levene testi ile test edilmiştir. Buna göre, alt ölçek puan dağılımları ortalamaları arası fark analizlerinde parametrik analiz teknikleri kullanılmıştır. Bu kapsamda; katılımcı öğretmenlerin alt ölçek puanlarının; cinsiyet, eğitim düzeyi ve yerleşim yeri değişkenlerine göre farklılaşıp farklılaşmadığını belirlemek için bağımsız gruplar t-testi; örneklem grubunu oluşturan öğretmenlerinin alt ölçek puanlarının; branş, kıdem, okul türü ve sını mevcudu değişkenlerine göre farklılaşıp farklılaşmadığını belirlemek için tek yönlü ANOVA; ANOVA sonrasında elde edilen farkın hangi gruplar arasında olduğunu belirlemek için Hocgberg GT2 testi kullanılmıştır.

\section{Bulgular}

\section{Öğretmenlerin Hesap Verebilirlik Eğilim Puanlarının Dağılımına İlişkin Bulgular}

Öğretmenlerin hesap verebilirlik eğilimleri alt ölçek puanlarına ilişkin değerler Tablo 2'de sunulmuştur. Buna göre, öğretmenlerin dişsal hesap verebilirlik eğilimleri normal dağılım $(X=11.92$, SS=2.56), içsel hesap verebilirlik $(X=24.84, S S=5.34)$ ve bireysel hesap verebilirlik eğilimleri $(X=37.1$, $S S=6.70)$ ise sola çarpık dağılım göstermektedir. Öğretmenler dışsal hesap 
verebilirlik eğilimlerini orta düzeyde, içsel ve bireysel hesap verebilirliklerini ise yüksek düzeyde değerlendirmişlerdir.

Tablo 2. Öğretmenlerin Hesap Verebilirlik Eğilimleri Alt Ölçek Puanlarının Dağıllmına İlişkin İstatistikler

\begin{tabular}{llllll}
\hline Alt Ölçekler & $n$ & $X$ & SS & Çarpıklık & Basıklık \\
\hline Dişsal Hesap Verebilirlik & 226 & 11.92 & 2.56 & -.236 & -.231 \\
İçsel Hesap Verebilirlik & 226 & 24.84 & 5.34 & -2.082 & 4.524 \\
Bireysel Hesap Verebilirlik & 226 & 37.1 & 6.70 & -1.691 & 3.713 \\
\hline
\end{tabular}

\section{Öğretmenlerin Hesap Verebilirlik Algılarındaki Farklılıklar Üzerine Bulgular}

Öğretmenlerin bireysel hesap verebilirlik eğilimleri üzerindeki olası okul yerleşim yerinin etkisini tespit etmek amacıyla gerçekleştirilen bağımsız örneklemler t-testi sonuçları Tablo 3'te sunulmuştur. Buna göre, köy ve ilçelerde görev yapan öğretmenlerin $(\mathrm{M}=11.76, \mathrm{SD}=2.52)$ ve il merkezlerinde görev yapan öğretmenlerin $(\mathrm{M}=11.96, \mathrm{SD}=2.56)$ dışsal hesap verebilirlik eğilimleri puan ortalamaları birbirine yakındır. Ortalama puanlar arası fark anlamlı değildir $\mathrm{t}(224)=-.521, \mathrm{p}>$.05. Öğretmenlerin görev yaptığı yerleşim yerinin dışsal hesap verebilirlik eğilimlerine etkisi oldukça küçüktür ( $\mathrm{d}=$ .078). Aynı şekilde, köy ve ilçelerde görev yapan öğretmenlerin $(\mathrm{M}=25.08$, $\mathrm{SD}=5.52)$ ve il merkezinde görev yapan öğretmenlerin $(M=25.02, S D=5.34)$ içsel hesap verebilirlik eğilimleri ortalamaları oldukça benzerdir, ve aralarındaki ortalama fark1 anlamlı değildir $\mathrm{t}(224)=.074, \mathrm{p}>.05$. Yerleşim yeri değişkeninin öğretmenlerin içsel hesap verebilirlik eğilimine etkisi de oldukça düşük seviyededir ( $\mathrm{d}=.011)$. Öğretmenlerin bireysel hesap verebilirlik eğilimleri köy ve ilçe puan ortalamalarıla $(\mathrm{M}=37.0, \mathrm{SD}=7.00)$ il merkezleri puan ortalamaları ( $\mathrm{M}=37.1, \mathrm{SD}=6.60)$ birbirleriyle benzerdir, ve ortalamalar arası fark anlamlı değildir $\mathrm{t}(224)=-.099, \mathrm{p}>.05$. Yerleşim yeri değişkeninin öğretmenlerin bireysel hesap verebilirlik eğilimlerine etkisi de oldukça küçüktür $(\mathrm{d}=-.015)$. 
Tablo 3. Öğretmenlerin Bireysel Hesap Verebilirlikleri Alt-ölçeklerinin Yerleşim Yeri Değişkenine Göre Bağımsız Örneklemler t-testi Sonuçları

\begin{tabular}{|c|c|c|c|c|c|c|c|}
\hline Ölçek & Yerleșim & $n$ & $X$ & SS & $t$ & $p$ & Cohend \\
\hline \multirow{2}{*}{ Dişsal HV } & Köy/İlçe & 60 & 11.76 & 2.52 & \multirow{2}{*}{$-.521^{*}$} & \multirow{2}{*}{.60} & \multirow{2}{*}{-.078} \\
\hline & İl/B.Şehir & 166 & 11.96 & 2.56 & & & \\
\hline \multirow{2}{*}{ İçsel HV } & Köy/İlçe & 60 & 25.08 & 5.52 & \multirow{2}{*}{$.074^{*}$} & \multirow{2}{*}{.94} & \multirow{2}{*}{.011} \\
\hline & İl/B.Şehir & 166 & 25.02 & 5.34 & & & \\
\hline \multirow{2}{*}{$\begin{array}{l}\text { Bireysel } \\
\text { HV }\end{array}$} & Köy/İlçe & 60 & 37.0 & 7.00 & \multirow{2}{*}{$-.099^{*}$} & \multirow{2}{*}{.92} & \multirow{2}{*}{-.015} \\
\hline & íl/B.Şehir & 166 & 37.1 & 6.60 & & & \\
\hline
\end{tabular}

$S D=224,{ }^{*}$ Gruplar arası varyanslar eşittir.

Öğretmenlerin bireysel hesap verebilirlik eğilimleri üzerindeki olası alınan eğitim düzeyi etkisini tespit etmek amacıyla gerçekleştirilen bağımsız örneklemler t-testi sonuçları Tablo 4'te sunulmuştur. Buna göre, lisans mezunu olan öğretmenlerin $(\mathrm{M}=11.88, \mathrm{SS}=2.68)$ ve yüksek lisans veya doktora yapan öğretmenlerin $(\mathrm{M}=12.04, \mathrm{SS}=2.24)$ dışsal hesap verebilirlik eğilimleri puan ortalamaları oldukça benzerdir. Ortalama puanlar arası fark anlamlı değildir $\mathrm{t}(224)=-.405, \mathrm{p}>$.05. Öğretmenlerin eğitim düzeylerinin dışsal hesap verebilirlik eğilimlerine etkisi küçüktür ( $\mathrm{d}=-.064)$. Aynı şekilde, lisans eğitimi alan öğretmenlerin $(M=24.78, S S=5.70)$ ve yüksek lisans öğrenimi gören öğretmenlerin $(\mathrm{M}=25.80, \mathrm{SS}=4.20)$ içsel hesap verebilirlik eğilimleri ortalamaları da oldukça benzerdir, ve aralarındaki ortalama farkı anlamlı değildir $\mathrm{t}(224)=-1.241, \mathrm{p}>$.05. Eğitim düzeyinin öğretmenlerin içsel hesap verebilirlik eğilimine etkisi küçük düzeydedir $(\mathrm{d}=-.204)$. Öğretmenlerin bireysel hesap verebilirlik eğilimleri puanlarının lisans grubu ortalamalarıla $(M=36.8, S S=$ 7.19) yüksek lisans grubu ortalamaları $(\mathrm{M}=38.1, \mathrm{SD}=4.99)$ birbirleriyle benzerdir, ve ortalamalar arası fark anlamlı değildir $t(224)=-1.265, p>05$. Eğitim düzeyinin öğretmenlerin bireysel hesap verebilirlik eğilimlerine etkisi küçüktür $(\mathrm{d}=-.210)$.

Tablo 4. Öğretmenlerin Bireysel Hesap Verebilirlikleri Alt-Ölçeklerinin Eğitim Düzeyi Değişkenine Göre Bă̆ımsız Örneklemler t-testi Sonuçları

\begin{tabular}{llllllll}
\hline Ölçek & Eğitim Düz. & $n$ & $X$ & $S S$ & $t$ & $p$ & Cohen d \\
\hline \multirow{2}{*}{ Dişsal HV } & Lisans & 169 & 11.88 & 2.68 & $-.405^{*}$ & \multirow{2}{*}{.69} & -.064 \\
\cline { 2 - 8 } & Yüksek Lis. & 57 & 12.04 & 2.24 & & \\
\hline \multirow{2}{*}{ İçsel HV } & Lisans & 169 & 24.78 & 5.70 & $-1.241^{*}$ & \multirow{2}{*}{.22} & -.204 \\
\cline { 2 - 8 } & Yüksek Lis. & 57 & 25.80 & 4.20 & & \\
\hline \multirow{2}{*}{$\begin{array}{l}\text { Bireysel } \\
\text { HV }\end{array}$} & Lisans & 169 & 36.8 & 7.19 & $-1.265^{*}$ & \multirow{2}{*}{.21} & -.210 \\
\cline { 2 - 6 } & Yüksek Lis. & 57 & 38.1 & 4.99 & & &
\end{tabular}

$S D=224,{ }^{*}$ Gruplar arası varyanslar eşittir. 
Öğretmenlerin bireysel hesap verebilirlik eğilimleri üzerindeki cinsiyet faktörünün etkisini tespit etmek amacıyla gerçekleştirilen bağımsız örneklemler t-testi sonuçları Tablo 5'te sunulmuştur. Buna göre, kadın öğretmenlerin $(\mathrm{M}=11.52, \mathrm{SS}=2.28)$ ve erkek öğretmenlerin $(\mathrm{M}=12.20$, SS $=2.72$ ) dişsal hesap verebilirlik eğilimleri puan ortalamaları oldukça benzerdir. Ortalama puanlar arası fark anlamlıdır t(224) $=-1.987, \mathrm{p}<.05$, ve öğretmenlerin cinsiyet düzeylerinin dışsal hesap verebilirlik eğilimlerine etkisi küçüktür $(\mathrm{d}=-.271)$. Aynı şekilde, kadın öğretmenlerin $(\mathrm{M}=25.56$, SS = 4.14) erkek öğretmenlerin ( $\mathrm{M}=24.66, \mathrm{SS}=6.05)$ içsel hesap verebilirlik eğilimleri ortalamaları da oldukça benzerdir, ve aralarındaki ortalama farkı anlamlı değildir $t(224)=1.256, p>.05$. Cinsiyetin öğretmenlerin içsel hesap verebilirlik eğilimine etkisi küçük düzeydedir ( $\mathrm{d}=.174)$. Öğretmenlerin bireysel hesap verebilirlik eğilimleri puanlarının kadın grubu ortalamalariyla $(\mathrm{M}=37.3, \mathrm{SS}=5.19)$ erkek grubu ortalamaları $(\mathrm{M}=36.9, \mathrm{SS}=$ 7.59) birbirleriyle benzerdir, ve ortalamalar arası fark anlamlı değildir $\mathrm{t}(224)=.445, \mathrm{p}>.05$. Cinsiyetin öğretmenlerin bireysel hesap verebilirlik eğilimlerine etkisi ise çok küçüktür $(\mathrm{d}=.062)$.

Tablo 5. Öğretmenlerin Bireysel Hesap Verebilirlikleri Alt-Ölçeklerinin Cinsiyet Değişkenine Göre Bağımsız Örneklemler t-testi Sonuçları

\begin{tabular}{|c|c|c|c|c|c|c|c|}
\hline Ölçek & Cinsiyet & $N$ & $X$ & $S S$ & $t$ & $p$ & Cohend \\
\hline \multirow{2}{*}{ Dişsal HV } & Kadın & 96 & 11.52 & 2.28 & \multirow{2}{*}{$-1.987^{*}$} & \multirow{2}{*}{.04} & \multirow{2}{*}{-.271} \\
\hline & Erkek & 130 & 12.20 & 2.72 & & & \\
\hline \multirow{2}{*}{ İçsel HV } & Kadın & 96 & 25.56 & 4.14 & \multirow{2}{*}{$1.256^{*}$} & \multirow{2}{*}{.21} & \multirow{2}{*}{.174} \\
\hline & Erkek & 130 & 24.66 & 6.05 & & & \\
\hline \multirow{2}{*}{ Bireysel HV } & Kadın & 96 & 37.3 & 5.19 & \multirow{2}{*}{$.445^{* *}$} & \multirow{2}{*}{.66} & \multirow{2}{*}{.062} \\
\hline & Erkek & 130 & 36.9 & 7.59 & & & \\
\hline
\end{tabular}

$S D=224,{ }^{*}$ Gruplar arası varyanslar eşittir, ${ }^{* *}$ Gruplar arası varyanslar eşit değildir

Tablo 6'da öğretmenlerin bireysel hesap verebilirlik alt ölçek puanlarının sinıf mevcudu faktör düzeylerine göre ortalamaları ve standart sapmaları sunulmuştur. Varyans analizi, sınıf mevcudunun dört düzeyi için öğretmenlerin dışsal hesap verebilirlik puanları ortalamaları $\mathrm{F}(3,222)=.658, \mathrm{p}>.05, \eta 2$ $=.008$, içsel hesap verebilirlik puanları ortalamaları $\mathrm{F}(3,222)=.840, \mathrm{p}>.05, \eta 2$ $=.011$, ve bireysel hesap verebilirlik puanları ortalamaları $\mathrm{F}(3,222)=1.10, \mathrm{p}>$ $.05, \eta 2=.014$ arasında anlamlı bir farklılık olmadığını göstermektedir. 
Tablo 6. Bireysel Hesap Verebilirlik Eğilimleri Alt Ölçek Puanlarının Sınıf Mevcudu Değişkenine Göre Tek Yönlü Varyans Analizi (ANOVA) Sonuçları

\begin{tabular}{|c|c|c|c|c|c|c|c|c|c|c|c|}
\hline \multirow{2}{*}{ Ölçek } & \multirow{2}{*}{$\begin{array}{l}\text { Sinif } \\
\text { mevcudu* }\end{array}$} & \multicolumn{4}{|c|}{$n, X$ ve $S D$} & \multicolumn{3}{|c|}{ ANOVA Sonuçları } & \multirow[b]{2}{*}{$\mathbf{F}$} & \multirow[b]{2}{*}{$\mathrm{p}$} & \multirow[b]{2}{*}{$\eta 2$} \\
\hline & & & $X$ & $S D$ & Kaynak & KT & Df & KO & & & \\
\hline \multirow{5}{*}{ 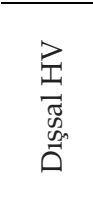 } & $1-10$ & 30 & 12.44 & 2.24 & G.Aras1 & 20.264 & 3 & 6.755 & .658 & .57 & .008 \\
\hline & 11-20 & 37 & 11.60 & 2.64 & G.İçi & 2279.510 & 222 & 10.268 & & & \\
\hline & $21-30$ & 115 & 11.84 & 2.72 & Toplam & 2299.774 & 225 & & & & \\
\hline & $30+$ & 44 & 11.96 & 2.20 & & & & & & & \\
\hline & Toplam & 226 & 11.92 & 2.56 & & & & & & & \\
\hline \multirow{5}{*}{ 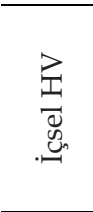 } & $1-10$ & 30 & 26.10 & 4.66 & G.Aras1 & .395 & 3 & .132 & .840 & .47 & .011 \\
\hline & $11-20$ & 37 & 24.75 & 5.92 & G.İçi & 34.832 & 222 & .157 & & & \\
\hline & $21-30$ & 115 & 25.13 & 5.13 & Toplam & 35.227 & 225 & & & & \\
\hline & $30+$ & 44 & 24.24 & 5.87 & & & & & & & \\
\hline & Toplam & 226 & 25.02 & 5.35 & & & & & & & \\
\hline \multirow{5}{*}{ 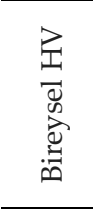 } & $1-10$ & 30 & 38.74 & 5.75 & G.Aras1 & .296 & 3 & .099 & 1.10 & .34 & .014 \\
\hline & $11-20$ & 37 & 36.55 & 7.64 & G.İçi & 19.776 & 222 & .089 & & & \\
\hline & $21-30$ & 115 & 37.15 & 6.49 & Toplam & 20.072 & 225 & & & & \\
\hline & $30+$ & 44 & 36.36 & 6.97 & & & & & & & \\
\hline & Toplam & 226 & 37.11 & 6.69 & & & & & & & \\
\hline
\end{tabular}

*Gruplar arası varyanslar eşittir.

Tablo 7'de öğretmenlerin bireysel hesap verebilirlik alt ölçek puanlarının branş faktör düzeylerine göre ortalamaları ve standart sapmaları sunulmuştur. Öğretmen branşları Liselere Geçiş Sınavı ve Yükseköğretim Kurumları Sınavında soru gelen branşlar (Matematik, Fen Bilimleri, Türkçe, Sosyal Bilimler ve İngilizce), ilkokul dersleri, ortaöğretim dersleri ve diğer dersler olarak gruplandırılmıştır. Varyans analizi, branş faktörünün dört düzeyi için öğretmenlerin dışsal hesap verebilirlik puanları ortalamaları $\mathrm{F}(3,222)=.773, \mathrm{p}>.05, \eta 2=.010$, içsel hesap verebilirlik puanları ortalamalar1 $\mathrm{F}(3,222)=.457, \mathrm{p}>.05, \mathrm{\eta} 2=.006$, ve bireysel hesap verebilirlik puanlar1 ortalamaları $\mathrm{F}(3,222)=.621, \mathrm{p}>.05, \eta 2=.008$ arasinda anlamlı bir farklılık olmadığını göstermektedir. 
Tablo 7. Bireysel Hesap Verebilirlik Eğilimleri Alt Ölçek Puanlarının Branş Değişkenine Göre Tek Yönlü Varyans Analizi (ANOVA) Sonuçları

\begin{tabular}{|c|c|c|c|c|c|c|c|c|c|c|c|}
\hline \multirow[b]{2}{*}{ Ölçek } & \multirow[b]{2}{*}{ Branş* } & \multicolumn{4}{|c|}{$n, X$ ve $S D$} & \multicolumn{6}{|c|}{ ANOVA Sonuçları } \\
\hline & & $N$ & $X$ & $S D$ & Kaynak & KT & Df & KO & F & $\mathbf{P}$ & $\eta 2$ \\
\hline \multirow{5}{*}{ 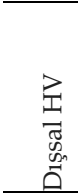 } & LGS/YKS & 151 & 11.8 & 2.58 & G.Aras1 & 23.788 & 3 & 7.929 & .773 & .51 & .010 \\
\hline & Okul D. & 30 & 12.6 & 2.75 & G.İçi & 2275.986 & 222 & 10.252 & & & \\
\hline & Ana/Sinif & 26 & 11.8 & 2.42 & Toplam & 2299.774 & 225 & & & & \\
\hline & Diğer & 19 & 11.7 & 2.16 & & & & & & & \\
\hline & Toplam & 226 & 11.8 & 2.55 & & & & & & & \\
\hline \multirow{5}{*}{ 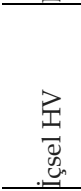 } & LGS/YKS & 151 & 24.8 & 5.5 & G.Aras1 & .216 & 3 & .072 & .457 & .71 & .006 \\
\hline & Okul D. & 30 & 24.9 & 5.9 & G.İçi & 35.011 & 222 & .158 & & & \\
\hline & Ana/Sınıf & 26 & 26.0 & 3.3 & Toplam & 35.227 & 225 & & & & \\
\hline & Diğer & 19 & 25.4 & 5.7 & & & & & & & \\
\hline & Toplam & 226 & 25.0 & 5.3 & & & & & & & \\
\hline \multirow{5}{*}{ 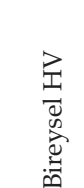 } & LGS/YKS & 151 & 36.8 & 6.68 & G.Aras1 & .167 & 3 & .056 & .621 & .60 & .008 \\
\hline & Okul D. & 30 & 37.6 & 7.92 & G.İçi & 19.905 & 222 & .090 & & & \\
\hline & Ana/Sinıf & 26 & 38.1 & 4.68 & Toplam & 20.072 & 225 & & & & \\
\hline & Diğer & 19 & 37.3 & 7.22 & & & & & & & \\
\hline & Toplam & 226 & 37.1 & 6.69 & & & & & & & \\
\hline
\end{tabular}

Tablo 8' de öğretmenlerin bireysel hesap verebilirlik alt ölçek puanlarının görev yapılan okul türü faktör düzeylerine göre ortalamaları ve standart sapmaları sunulmuş̧tur. Varyans analizi, okul türü faktörünün beş düzeyi için öğretmenlerin dişsal hesap verebilirlik puanları ortalamaları $\mathrm{F}(4,221)$ $=.637, \mathrm{p}>.05, \mathrm{\eta} 2=.011$, ve bireysel hesap verebilirlik puanlar1 ortalamalar1 $\mathrm{F}(4,221)=2.404, \mathrm{p}>.05, \mathrm{\eta} 2=.042$ arasinda arası anlamlı bir farklılık olmadığını, buna karşın, içsel hesap verebilirlik puanları ortalamaları $F(4,221)$ $=3.113, \mathrm{p}<.05, \eta 2=.053$ arasında anlamlı bir fark olduğunu göstermektedir. ANOVA sonrası çoklu karşılaştırmaları yapmak amacıyla, öncelikle Levene's testi yapılarak grup dağılımlarının varyanslarının homojen olduğu hipotezi test edilerek kabul edildiğinden [p>.05], ve aynı zamanda grup örneklem büyüklüklerinin bir birlerinden çok farklı oluşundan dolayı Hochberg GT2 çoklu karşılaştırma analizi uygulanmıştır. Bunun sonucunda, içsel hesap verebilirlik puanlarının Anadolu Liseleri ile Fen ve Sosyal Bilimler Liseleri, Mesleki Liseler ve Anaokulu/ilkokullar arasında Anadolu Liseleri grubu lehine istatistiksel olarak anlamlı farklllıklar saptanmıştır $[\mathrm{p}<.05]$. Öte taraftan, okul türü faktörü öğretmenlerin içsel 
hesap verebilirlik eğilimlerindeki varyansın yalnızca \% 5,3'ünü açıklamaktadir.

Tablo 8. Bireysel Hesap Verebilirlik Eğilimleri Alt Ölçek Puanlarının Okul Türü Değişkenine Göre Tek Yönlü Varyans Analizi (ANOVA) Sonuçları

\begin{tabular}{|c|c|c|c|c|c|c|c|c|c|c|c|}
\hline \multirow{2}{*}{ Ölçek } & \multirow[b]{2}{*}{ Okul Türü } & \multicolumn{4}{|c|}{$n, X$ ve $S D$} & \multicolumn{6}{|c|}{ ANOVA Sonuçları } \\
\hline & & $N$ & $X$ & $S D$ & Kaynak & KT & Df & KO & F & $\mathrm{p}$ & $\eta 2$ \\
\hline \multirow{7}{*}{ 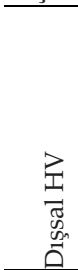 } & Fen/Sos & 36 & 12.0 & 2.34 & G.Arası & 26.209 & 4 & 6.552 & .637 & .64 & .011 \\
\hline & Anad.L. & 32 & 11.3 & 2.86 & G.İçi & 2273.565 & 221 & 10.28 & & & \\
\hline & $\begin{array}{l}\text { İHL. } \\
\end{array}$ & 12 & 11.6 & 2.86 & Toplam & 2299.774 & 225 & & & & \\
\hline & Mes.L. & 41 & 12.0 & 2.57 & & & & & & & \\
\hline & Ortaokul & 87 & 12.1 & 2.42 & & & & & & & \\
\hline & Ana/İlk & 18 & 12.4 & 2.16 & & & & & & & \\
\hline & Total & 226 & 11.9 & 2.55 & & & & & & & \\
\hline \multirow{7}{*}{ 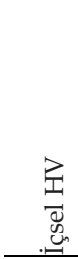 } & Fen/Sos & 36 & 25.5 & 5.98 & G.Aras1 & 1.879 & 4 & .470 & 3.113 & .02 & .053 \\
\hline & Anad.L. & 32 & 21.5 & 7.37 & G.İçi & 33.348 & 221 & .151 & & & \\
\hline & İHL. & 12 & 26.0 & 3.26 & Toplam & 35.227 & 225 & & & & \\
\hline & Mes.L. & 41 & 25.5 & 4.41 & & & & & & & \\
\hline & Ortaokul & 87 & 26.6 & 5.99 & & & & & & & \\
\hline & Ana/İlk & 18 & 26.5 & 5.08 & & & & & & & \\
\hline & Total & 226 & 25.0 & 5.35 & & & & & & & \\
\hline \multirow{7}{*}{ 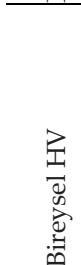 } & Fen/Sos & 36 & 37.7 & 7.55 & G.Arası & .837 & 4 & .209 & 2.404 & .05 & .042 \\
\hline & Anad.L. & 32 & 33.0 & 9.23 & G.İçi & 19.235 & 221 & .087 & & & \\
\hline & İHL. & 12 & 37.8 & 4.80 & Toplam & 20.072 & 225 & & & & \\
\hline & Mes.L. & 41 & 37.6 & 5.57 & & & & & & & \\
\hline & Ortaokul & 87 & 38.9 & 6.91 & & & & & & & \\
\hline & Ana/İlk & 18 & 39.1 & 5.73 & & & & & & & \\
\hline & Total & 226 & 37.1 & 6.69 & & & & & & & \\
\hline
\end{tabular}

Tablo 9' da öğretmenlerin bireysel hesap verebilirlik alt ölçek puanlarının kıdem faktörü düzeylerine göre ortalamaları ve standart sapmaları sunulmuştur. Varyans analizi, kıdem faktörünün beş düzeyi için öğretmenlerin dışsal hesap verebilirlik puanları ortalamaları $\mathrm{F}(4,221)=1.611, \mathrm{p}>.05$, $\eta 2=.028$, içsel hesap verebilirlik puanları ortalamaları $\mathrm{F}(4,221)=.993, \mathrm{p}>$ $.05, \eta 2=.017$, ve bireysel hesap verebilirlik puanları ortalamaları $\mathrm{F}(4,221)$ $=1.080, \mathrm{p}>.05, \eta 2=.019$ arasında anlamlı bir farklılık olmadığını göstermektedir. Ayrıca, cinsiyet faktörünün öğretmenlerin dışsal, içsel ve bireysel hesap verebilirliklerine olan etkileri oldukça küçüktür. 
Tablo 9. Bireysel Hesap Verebilirlik Eğilimleri Alt Ölçek Puanlarının Kıdem Değişkenine Göre Tek Yönlü Varyans Analizi (ANOVA) Sonuçları

\begin{tabular}{|c|c|c|c|c|c|c|c|c|c|c|c|}
\hline \multirow{2}{*}{ Ölçek } & \multirow[b]{2}{*}{ Kidem } & \multicolumn{4}{|c|}{$n, X$ ve $S D$} & \multicolumn{6}{|c|}{ ANOVA Sonuçlart } \\
\hline & & $N$ & $X$ & $S D$ & Kaynak & KT & Df & $\mathrm{KO}$ & $\mathrm{F}$ & $P$ & $\eta 2$ \\
\hline \multirow{6}{*}{ 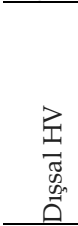 } & $1-5 y 11$ & 14 & 12.5 & 2.32 & G.Aras1 & 65.174 & 4 & 16.293 & 1.611 & .17 & .028 \\
\hline & 6-10yıl & 34 & 11.7 & 2.46 & G.İçi & 2234.601 & 221 & 10.111 & & & \\
\hline & 11-15yıl & 67 & 11.5 & 2.32 & Toplam & 2299.774 & 225 & & & & \\
\hline & 16-20yıl & 71 & 11.9 & 2.79 & & & & & & & \\
\hline & $21+\mathrm{y} 1 \mathrm{l}$ & 40 & 12.7 & 2.56 & & & & & & & \\
\hline & Total & 226 & 11.9 & 2.55 & & & & & & & \\
\hline \multirow{6}{*}{ 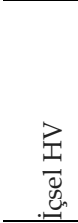 } & $1-5 \mathrm{y} 1 \mathrm{l}$ & 14 & 27.5 & 2.00 & G.Arası & .622 & 4 & .155 & .993 & .41 & .017 \\
\hline & $6-10 y_{1}$ & 34 & 24.9 & 5.09 & G.İçi & 34.606 & 221 & .157 & & & \\
\hline & 11-15yıl & 67 & 25.0 & 5.33 & Toplam & 35.227 & 225 & & & & \\
\hline & 16-20yıl & 71 & 24.8 & 5.40 & & & & & & & \\
\hline & $\underline{21+\mathrm{y} 1 \mathrm{l}}$ & 40 & 24.7 & 6.23 & & & & & & & \\
\hline & Total & 226 & 25.0 & 5.35 & & & & & & & \\
\hline \multirow{6}{*}{ 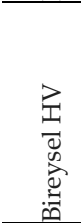 } & $1-5 y 11$ & 14 & 40.2 & 2.82 & G.Arası & .385 & 4 & .096 & 1.080 & .36 & .019 \\
\hline & 6-10yıl & 34 & 36.8 & 6.49 & G.İçi & 19.687 & 221 & .089 & & & \\
\hline & 11-15yıl & 67 & 36.7 & 6.49 & Toplam & 20.072 & 225 & & & & \\
\hline & 16-20yıl & 71 & 36.9 & 6.68 & & & & & & & \\
\hline & $21+\mathrm{y} 1 \mathrm{l}$ & 40 & 37.5 & 8.00 & & & & & & & \\
\hline & Total & 226 & 37.1 & 6.69 & & & & & & & \\
\hline
\end{tabular}

*Gruplar arası varyanslar eşittir.

\section{Tartışma, Sonuç ve Öneriler}

Elde edilen bulgular özetlendiğinde, Türkiye' de görev yapan öğretmenlerin üst yönetim birimleri ile olan etkileşimlerinde öğrenci kazanım düzeyleri bilgisine dayanılarak ödüllendirilmeyi veya yaptırıma maruz kalmayı görevlerinin bir parçası olarak görme eğilimleri ne çok düşük ne de çok yüksek düzeydedir. Öğretmenlerin dişsal hesap verebilirliklerinde yanlızca cinsiyetin belirleyici olduğu tespit edilmiştir. Erkek öğretmenlerin bayan öğretmenlere kıyasla dişsal hesap verebilirlik eğilimlerinin anlamlı bir şekilde daha üst düzeyde olduğu görülmektedir. Diğer taraftan, öğretmenlerin üst yönetimle olan etkileşimlerinde öğretim görevlerine ilişkin meslek etiğine uygun davranma, mesleki yeterlilik ve gelişimlerini sağlama yönündeki eğilimlerinin dışsal hesap verebilirlik eğilimlerine kıyasla daha yüksek düzeyde olduğu görülmektedir. Buna karşın, okulun bulunduğu yerleşim yeri, görev yaptığı sınıfın mevcudu gibi kurumsal bağlam ile öğretmenlerin branşları, eğitim düzeyleri ve mesleki tecrübeleri gibi bireysel bağlam özellikleri öğretmenlerin üst yönetim birimleri ile olan hesap verebilirlik 
ilişkilerinde içsel ve dışsal hesap verebilirlik düzeylerini belirleyen önemli faktörler arasında yer almamaktadır. Yanlızca, Anadolu liselerinde görev yapan öğretmenlerin diğer okul türlerinde görev yapanlara kıyasla içsel hesap verebilirlik eğilimleri daha yüksek düzeydedir.

Öğretmenlerin hesap verebilirlikleri üzerine ulusal literatüre bakıldığında da benzer bulgulara ulaşıldığı görülmektedir. Erdağ ve Karadağ (2018), Kantos (2010) ve Bakioğlu ve Salduz (2014) öğretmenlerin akademik başarının artırılmasına yönelik öğretmenlerin okul müdürü, üst yönetim ve müfettişlere karşı yüksek düzeyde hesap verme zorunluluğu hissettiklerini rapor etmişlerdir. Bunlara ek olarak, Erdağ ve Karadağ (2017), öğretmenlerin dışsal hesap verebilirlik politikalarını kısmen desteklediklerini belirtmektedir. Öğrencilerin kazanım düzeylerinin geliştirilmesinde öğretmenlerin program hedeflerinden sorumlu tutulmaları, öğrenci kazanım değerlendirilmelerinin yapılması, mesleki bilginin üretilmesi ve kullanılması ile başarılı öğretmenlerin ödüllendirilmesi politikalarına öğretmenler olumlu bakarken, olumsuz sonuç durumunda öğretmenlere yaptırım uygulanması ve cezalandırılması politikasına olumsuz bakmakta, öğrencilerin başarısızlıklarından dolayı kendilerinin cezalandırılmasının adil olmadığına inanmaktadır (Bakioğlu ve Salduz, 2014; Sabancı, 1999; Seyhani, Özder ve Konedralı, 2009; Sumak ve Roşan, 2015). Ayrıca, öğretmen performans değerlendirmeleri okullara rekabet, iş yükü, baskı ve endişe getireceğinden ve adil olamayacağı endişelerinden dolayı öğretmenlerce destek görmemektedir (Soydan, 2012; Soydan, Abalı ve Kalsen, 2014; Üstünkal, 2013). Öte taraftan, Erdağ ve Karadağ (2017) öğrencilerin kazanımlarının geliştirilmesinde öğretmenlerin en çok mesleki yeterlilikler, mesleki gelişim ve aynı zamanda mesleki bilginin üretilmesi ve kullanımı politikalarına çok önemsedikleri ve desteklediklerini belirtmektedir. Bazı çalışmalarda da nitelikli ve başarılı bir öğretim için öğretmenlerin mesleki bilgi, beceriler ve tutumlarına ilişkin yeterlikleri ile bilgi ve beceri düzeylerinin artırılmasının gerekliliğine inandıkları gösterilmiştir (Ekici, 2014; Koçak, Turan ve Aydoğdu, 2012; Mete ve Gürsoy, 2014). Öğretmenler mesleki gelişimi değişen koşullar ve teknolojilere ayak uydurma, bilgi ve beceriyi artırma, kendini yenileme ve güncel tutma olarak algilamakta ve bir gereklilik olarak görmektedir (Altun ve Vural, 2012; Ceylan ve Özdemir, 2016; Gökmenoğlu, Beyazova ve K1lıçoğlu, 2015; Boydak, Polat ve Şener, 2014; Uştu, Mentiş ve Sever, 2016). Erdağ ve Karadağ (2018) öğretmenlerin hesap verme duygularının aynı 
şekilde kıdem, eğitim düzeyi, branşları ve okul türüne göre farklılık göstermediğini, öte taraftan, cinsiyetin de benzer şekilde hesap verme duygularında fark yarattığını belirlemiştir. Diğer bir deyişle, bayan öğretmenler erkeklere kıyasla veli ve öğrencilere karşı daha düşük düzeyde öğretim faaliyetlerine ilişkin bilgi verme, eylemlerini açılama ve haklılığını gösterme zorunluluğu hissettikleri gösterilmiştir. Bakioğlu ve Salduz (2014) da öğretmenlerin üst yönetim otoritelerine ve müfettişlere karşı hesap verme duygularının cinsiyet, branş, kıdem, okul türü ve eğitim düzeyine göre farklılık göstermediğini bildirmektedir.

Buradan hareketle, araştırmacılar, okul yöneticileri ve politika yapıcıları için bazı görevlerin ortaya çıktığı görülmektedir. Öncelikle, öğretmen hesap verebilirliğinin nasıl algılandığı ve yorumlandığı konusunda daha nitel yönelimli çalışmalara ihtiyaç vardır. Öğretmenlerin hesap verebilirliklerine ilişkin tecrübeleri ve yorumlamaları, hesap verebilirliği nasıl anlamlandırdıkları, bireysel, yapısal ve sosyal bağlam değişkenlerinin hesap verebilirlik anlamlarını nasıl etkilediği öğretmenlerin içsel dünyasının, örgüt yapısının ve sosyal çevrenin analizi ile daha derinlemesine keşfedilmelidir. Cinsiyetin öğretmenlerin dışsal hesap verebilirliğini, okul türünün de içsel hesap verebilirliklerini belirlemedeki rolleri başka coğrafyalarda yeniden test edilmeli ve detaylı olarak açıklanmalıdır. Ayrıca, öğretmenlerin hesap verebilirlik yorumlarını etkileyen yapısal, sosyal ve bireysel diğer faktörler ortaya çıkarılmalı, öğretmenlerin iyi oluşları, performansları, düşünme biçimleri ve motivasyonları gibi birçok özelliğin nasıl etkilendiği nitel ve nicel çalışmalarla gösterilmelidir. Ayrıca, unutulmamalıdır ki, öğretmenlerin dışa karşı kendilerini olduğundan daha iyi gösterme veya olumlu imaj yaratma çabası da öğretmenlerin içsel hesap verebilirliklerini olduğundan daha yüksek göstermelerine neden olmuş olabilir. Dolayısıyla, içsel ve dişsal hesap verebilirliğin olası nedenleri ve sonuçları üzerine yapılacak ilişkisel çalışmalarda bu değişken hesaba katılmalı ve etkisi kontrol edilmelidir.

Öte taraftan, hesap verebilirliklerini daha çok bilgi temelli anlamlandıran öğretmenlerin bilgi ihtiyaçlarını karşılayacak mesleki gelişim programlarının üretilmesi, yaygınlaştırılması ve kolay erişilebilir hale getirilmesi eğitim plancıları ve insan kaynakları yöneticileri için önemli bir görev olarak görülmelidir. Öğretmenlerin mesleki yeterliliklerini ve gelişimlerini destekleyecek daha etkili ve alternative programlara ve mekanizmalara ihtiyaç bulunmaktadır. Bu anlamda, eğitim fakültelerinin öğretmen 
yetiştirmeye ve geliştirmeye yönelik kapasitelerini ve motivasyonlarını attırmaya imkan sağlayacak yeni fikirlere ve uygulamalara acilen ihtiyaç vardır.

Yine, öğretmenlerin hem kendi performanslarına, hem de öğrencilerin performanslarına ilişkin anlamlı dönütlerin sağlanması gerekmektedir. Bunun için öncelikle öğrencilerin akademik performans bilgilerinin izlenmesi, ölçülmesi ve değerlendirilmesine ihtiyaç duyulmaktadır. Bu maksatla öğrenci performanslarını izleme ve değerlendirme sisteminin kurulması ve işletilmesi öğretmenlerin hesap verebilirliklerine önemli katkı sağlayacaktır. Bu anlamda, okullarda öğrenci ve öğretmen performans değerlendirme sistemlerinin hayata geçirilerek ödül ve ceza sistemi olarak kullanımından daha ziyade öğretimi geliştirici ve dönüştürücü bir değerlendirme özelliğine kavuşturulması öğretimin niteliğinin artırılmasına daha önemli bir katkı sunacaktır. Bu sistem aynı zamanda öğretmenlere ve okullara öğretime ilişkin yenilikçi olmalarına da imkan sağlayacaktır. Öğretmen ve yöneticilerin öğretime ilişkin yeni yöntem, teknik ve politika oluşturmalarında veriye dayalı üretilmiş bilgi sayesinde daha isabetli kararlar almalarına, etkili ve verimli uygulamalar geliştirmelerine imkan sağlanacaktır. Bu aynı zamanda Türkiye'nin insan, zaman ve maddi kaynaklarının israfını önlemeye yönelik çabalarına da destek sağlayacaktır.

\section{Destek}

Bu çalışma, Türkiye Bilimsel ve Teknolojik Araştırma Kurumu Başkanlığı (TÜBİTAK) bünyesinde desteklenen araştırma projesinin ilk sonuçlarına dayanılarak hazırlanmıştır. 


\title{
EXTENDED ABSTRACT
}

\section{Exploring Individual and Institutional Factors Affecting Teacher Personal Accountability Felt}

\author{
Coşkun Erda $\breve{g}$ \\ Aksaray University
}

In search for efficiency and effectiveness of the social systems, accountability is always a very fundemental concept. For this reason. school accountability is a worldwide policy of school improvement in spite of some variations from jurisdiction to jurisdiction. Through different dyadic accountability relations between administrative, professional and market units and educators, world education systems are trying to reach the expected higher level of student achievements. Including holding schools and teachers responsible for high academic standards in core curriculum, the measurement of students achievements, performance reporting, and applying rewards and sanctions based on performance information, accountability aims to make teachers and schools accountable, and make sure that teachers demonstrote appropriate teaching behaviours that help students learn more effectively. On the other hand, how to determine a teachers' accompanying level accountability in these accountability relations and determine the factors responsible for the variations in their accountability felt appears to be a big challange. Its subjective reality has been neglected and some objective methods have been used so far to estimate its level such as individual performance increase or the feedback given by the supervisor (Frink and Klimoski, 1998). This shortcoming does not allow us to sense and understand the subjective reality of their personal accountability dispositions although these have potential to impact their well-being, motivation, and performance (Cheng ve Tsui, 1999; Frink ve Ferris, 1998; Hall, Frink, Ferris, Hochwarter, Kacmar ve Bowen, 2003). Additionally, only limited number of studies addressed this issue, and there only exist few studies that determine and understand teachers answerability to different stakeholders from their own perspectives (Bakioğlu \& Salduz, 2014; Erdag ve Karadağ, 2018; Kardaş, 2019; Too, 1989; Yıldırım \& Yenipinar, 2019). From this point of view, understanding their subjective 
nature of personal accountability and identifying the factors that differentiate their level of accountability is crucial both for ensuring their wellbeing and effective teaching. It is also imprortant for it contributes to the international knowledge-base on the teacher personal accountability research through the evidence produced in Turkish context. Therefore, this study aims to describe teachers' personal fellings of external and internal accountability, and explore the factors that impact on their feelings. It seeks answers to the research questions, (i) what is the level of Turkish teachers' external, internal and personal accountability dispositions, and (ii) are there any diffrence between the teacher accountability dispositions with respect to teacher individual characteristics like gender, branch of teaching, education level, experience, and school characterisitics like its location, type, class size?

Following correlational design, 228 teachers at work in K-12 schools in Aksaray, Turkey, were randomly sampled, and their personal accountability dispositions were measured through the Turkish version of 'Teacher Personal Accountability Measure' adapted from the study by Rosenblatt (2017). Turkish version of the scale includes external accountability dimension ( 4 items, $\alpha=.65$ ) and internal accountability dimension (6 items, $\alpha=.95$ ).

Found that teachers do not feel strongly that monitoring student achievements and reporting to administrative units, and accepting performance-based rewards and sanctions were their duties (external accountability) (Mean=11.92; $\mathrm{SD}=2.56$ ), whereas they strongly feel that following professional ethics, raising professional competence and ensuring professional development (internal accountability) are among their duties in their teaching (Mean=24.84; $\mathrm{SD}=5.34)$.

Table 1. Distributions of the Teacher Personal Accountability Scales

\begin{tabular}{llllll}
\hline Scales & $N$ & $X$ & $S D$ & Skewness & Kurtosis \\
\hline Teacher External Accountability & 226 & 11.92 & 2.56 & -.236 & -.231 \\
Teacher Internal Accountability & 226 & 24.84 & 5.34 & -2.082 & 4.524 \\
Teacher Personal Accountability & 226 & 37.1 & 6.70 & -1.691 & 3.713 \\
\hline
\end{tabular}

Second, teachers' external accountability dispositions do not differentiate between the sub-groups of teachers' branch of teaching, education level, experience, and schools' locations and class size. Only male teachers fell more external accountability than the females. 
Table 2. Independent-samples t-test results, by School location, Gender, Education level

\begin{tabular}{|c|c|c|c|c|c|c|c|}
\hline Scale & Groups & $N$ & $X$ & $s d$ & $T$ & $p$ & Cohend \\
\hline \multirow{6}{*}{$\begin{array}{l}\text { Teacher } \\
\text { External } \\
\text { Accoun- } \\
\text { tability } \\
\text { (TEA) }\end{array}$} & Rural & 60 & 11.76 & 2.52 & \multirow{2}{*}{$-.521^{*}$} & \multirow{2}{*}{.60} & \multirow{2}{*}{-.078} \\
\hline & Urban & 166 & 11.96 & 2.56 & & & \\
\hline & Female & 96 & 11.52 & 2.28 & \multirow{2}{*}{$-1.987^{*}$} & \multirow{2}{*}{.04} & \multirow{2}{*}{-.271} \\
\hline & Male & 130 & 12.20 & 2.72 & & & \\
\hline & Graduate & 169 & 11.88 & 2.68 & \multirow{2}{*}{$-.405^{*}$} & \multirow{2}{*}{.69} & - \\
\hline & Post-graduate & 57 & 12.04 & 2.24 & & & .064 \\
\hline \multirow{6}{*}{$\begin{array}{l}\text { Teacher } \\
\text { Internal } \\
\text { Accoun- } \\
\text { tability } \\
\text { (TIA) }\end{array}$} & Rural & 60 & 25.08 & 5.52 & \multirow{2}{*}{$.074^{*}$} & \multirow{2}{*}{.94} & \multirow{2}{*}{.011} \\
\hline & Urban & 166 & 25.02 & 5.34 & & & \\
\hline & Female & 96 & 25.56 & 4.14 & \multirow{2}{*}{$1.256^{*}$} & \multirow{2}{*}{.21} & \multirow{2}{*}{.174} \\
\hline & Male & 130 & 24.66 & 6.05 & & & \\
\hline & Graduate & 169 & 24.78 & 5.70 & \multirow{2}{*}{$-1.241^{*}$} & \multirow{2}{*}{.22} & - \\
\hline & Post-graduate & 57 & 25.80 & 4.20 & & & .204 \\
\hline \multirow{6}{*}{$\begin{array}{l}\text { Teacher } \\
\text { Personal } \\
\text { Accoun- } \\
\text { tability } \\
\text { (TPA) }\end{array}$} & Rural & 60 & 37.0 & 7.00 & \multirow{2}{*}{$-.099^{*}$} & \multirow{2}{*}{.92} & \multirow{2}{*}{-.015} \\
\hline & Urban & 166 & 37.1 & 6.60 & & & \\
\hline & Female & 96 & 37.3 & 5.19 & \multirow{2}{*}{$.445^{* *}$} & \multirow{2}{*}{.66} & \multirow{2}{*}{.062} \\
\hline & Male & 130 & 36.9 & 7.59 & & & \\
\hline & Graduate & 169 & 36.8 & 7.19 & \multirow{2}{*}{$-1.265^{*}$} & \multirow{2}{*}{.21} & \multirow{2}{*}{-.210} \\
\hline & Post-graduate & 57 & 38.1 & 4.99 & & & \\
\hline
\end{tabular}

$D f=224,{ }^{*}$ Equal group variances

Third, teachers' internal accountability dispositions do not differentiate between the sub-groups of teachers' branch of teaching, education level, experience, gender, and schools' locations and class sizes. Only school level has small-size effect on their internal acccountability dispositions in that Anatolian school teachers feel more internally oriented accountability than other school teachers. (see Table 2, Table 3 and Table 4)

In the light of these findings, it is obvious there is a need for more evidence from different geographies and cultures on teachers accountability dispositions. The underlying reason why teachers strongly feel internal accountability in their teaching core curriculum while their feelings of external accountability is rather weak should also be further investigated and explored through qualitative researches. The reason why Anatolian high school teachers feel more internal accountability, and why the male teachers feel more external accountability compared to other groups of teachers should also be further investigated. Their relation should be also examined to other factors like teacher personality, school accountability environment characteristics, school culture and climate. Furthermore, development of high quality, needs-based, and easily accesible 
professional development and ethic programs should be regarded as an important task for education planners and human resources managers just because teachers feel their accountability more pedegogically knowledge-based. It also implies that there is a need to reform educational system to make a true alignment between curriculum standards, student evaluations and pre-service and in service professional development opportunities.

Table 3. ANOVA results of Accountability scales, by Class size and Branch of teaching

\begin{tabular}{|c|c|c|c|c|c|c|c|c|c|c|}
\hline & & & and $s d$ & & & ANOVA R & esults & & & \\
\hline Scale & Class size $^{*}$ & $n$ & $X$ & $S d$ & Treatmetns & SS & df & MSS F & $\mathrm{p}$ & $\eta 2$ \\
\hline & $1-10$ & 30 & 12.44 & 2.24 & Between & 20.264 & 3 & 6.755 .658 & .57 & .008 \\
\hline & $11-20$ & 37 & 11.60 & 2.64 & In & 2279.510 & 222 & 10.268 & & \\
\hline TEA & $21-30$ & 115 & 11.84 & 2.72 & Total & 2299.774 & 225 & & & \\
\hline & $30+$ & 44 & 11.96 & 2.20 & & & & & & \\
\hline & Total & 226 & 11.92 & 2.56 & & & & & & \\
\hline & $1-10$ & 30 & 26.10 & 4.66 & Between & .395 & 3 & $.132 \quad .840$ & .47 & .011 \\
\hline & $11-20$ & 37 & 24.75 & 5.92 & In & 34.832 & 222 & .157 & & \\
\hline TIA & $21-30$ & 115 & 25.13 & 5.13 & Total & 35.227 & 225 & & & \\
\hline & $30+$ & 44 & 24.24 & 5.87 & & & & & & \\
\hline & Total & 226 & 25.02 & 5.35 & & & & & & \\
\hline & $1-10$ & 30 & 38.74 & 5.75 & Between & .296 & 3 & .099 & .34 & .014 \\
\hline & $11-20$ & 37 & 36.55 & 7.64 & In & 19.776 & 222 & .089 & & \\
\hline TPA & $21-30$ & 115 & 37.15 & 6.49 & Total & 20.072 & 225 & & & \\
\hline & $30+$ & 44 & 36.36 & 6.97 & & & & & & \\
\hline & Total & 226 & 37.11 & 6.69 & & & & & & \\
\hline Scale & Teaching Branch* & $n$ & $X$ & $S d$ & Treatmetns & SS & df & MSS F & $\mathrm{p}$ & $\eta 2$ \\
\hline & ${ }^{* *} \mathrm{NEC}$ & 151 & 11.8 & 2.58 & Between & 23.788 & 3 & $\begin{array}{ll}7.929 & .773\end{array}$ & .51 & .010 \\
\hline & $* * * N-N E C$ & 30 & 12.6 & 2.75 & In & 2275.986 & 222 & 10.252 & & \\
\hline TEA & Class & 26 & 11.8 & 2.42 & Total & 2299.774 & 225 & & & \\
\hline & Other & 19 & 11.7 & 2.16 & & & & & & \\
\hline & Total & 226 & 11.8 & 2.55 & & & & & & \\
\hline & **NEC & 151 & 24.8 & 5.5 & Between & .216 & 3 & .072 & .71 & .006 \\
\hline & $* * * N-N E C$ & 30 & 24.9 & 5.9 & In & 35.011 & 222 & .158 & & \\
\hline TIA & Class & 26 & 26.0 & 3.3 & Total & 35.227 & 225 & & & \\
\hline & Other & 19 & 25.4 & 5.7 & & & & & & \\
\hline & Total & 226 & 25.0 & 5.3 & & & & & & \\
\hline & ${ }^{* *} \mathrm{NEC}$ & 151 & 36.8 & 6.68 & Between & .167 & 3 & .056 & .60 & .008 \\
\hline & ${ }^{* * *} \mathrm{~N}-\mathrm{NEC}$ & 30 & 37.6 & 7.92 & In & 19.905 & 222 & .090 & & \\
\hline TPA & Class & 26 & 38.1 & 4.68 & Total & 20.072 & 225 & & & \\
\hline & Other & 19 & 37.3 & 7.22 & & & & & & \\
\hline & Total & 226 & 37.1 & 6.69 & & & & & & \\
\hline
\end{tabular}

*Equal group variances, ${ }^{* *} N E C:$ Nationally examined courses, ${ }^{* * *} N-N E C:$ Non-nationaly examined courses 
Tablo 4. Accountability scales ANOVA results, by School type and Experience

\begin{tabular}{|c|c|c|c|c|c|c|c|c|c|c|c|}
\hline \multirow[b]{2}{*}{ Scale } & \multicolumn{5}{|c|}{$n, X$ and $s d$} & \multicolumn{3}{|c|}{ ANOVA Results } & \multirow[b]{2}{*}{$\mathbf{F}$} & \multirow[b]{2}{*}{ p } & \multirow[b]{2}{*}{$\eta 2$} \\
\hline & School type & & $X$ & $s d$ & $\begin{array}{l}\text { Treat- } \\
\text { ments }\end{array}$ & SS & df & MSS & & & \\
\hline \multirow{7}{*}{ TEA } & Science Sch. 3 & & 12.0 & 2.34 & Between & 26.209 & 4 & 6.552 & .637 & .64 & .011 \\
\hline & Anadolu L. 3 & 32 & 11.3 & 2.86 & In & 2273.565 & 221 & 10.288 & & & \\
\hline & Religious & 12 & 11.6 & 2.86 & Total & 2299.774 & 225 & & & & \\
\hline & Vocational & 41 & 12.0 & 2.57 & & & & & & & \\
\hline & Middle Sch. \& & & 12.1 & 2.42 & & & & & & & \\
\hline & $\begin{array}{l}\text { Primary } \\
\text { Sch. }\end{array}$ & 18 & 12.4 & 2.16 & & & & & & & \\
\hline & Total $\quad 2$ & 226 & 11.9 & 2.55 & & & & & & & \\
\hline \multirow{7}{*}{ TIA } & Science Sch. 3 & & 25.5 & 5.98 & Between & 1.879 & 4 & .470 & 3.113 & .02 & .053 \\
\hline & Anadolu L. 3 & 32 & 21.5 & 7.37 & In & 33.348 & 221 & .151 & & & \\
\hline & Religious & 12 & 26.0 & 3.26 & Total & 35.227 & 225 & & & & \\
\hline & Vocational & 41 & 25.5 & 4.41 & & & & & & & \\
\hline & Middle Sch. 8 & & 26.6 & 5.99 & & & & & & & \\
\hline & $\begin{array}{l}\text { Primary } \\
\text { Sch. }\end{array}$ & 18 & 26.5 & 5.08 & & & & & & & \\
\hline & Total & 226 & 25.0 & 5.35 & & & & & & & \\
\hline \multirow{7}{*}{ TPA } & Science Sch. 3 & 36 & 37.7 & 7.55 & Between & .837 & 4 & .209 & 2.404 & .05 & .042 \\
\hline & Anadolu L. 3 & 32 & 33.0 & 9.23 & In & 19.235 & 221 & .087 & & & \\
\hline & Religious & 12 & 37.8 & 4.80 & Total & 20.072 & 225 & & & & \\
\hline & Vocational & 41 & 37.6 & 5.57 & & & & & & & \\
\hline & Middle Sch. \& & & 38.9 & 6.91 & & & & & & & \\
\hline & $\begin{array}{l}\text { Primary } \\
\text { Sch. }\end{array}$ & 18 & 39.1 & 5.73 & & & & & & & \\
\hline & Total & 226 & 37.1 & 6.69 & & & & & & & \\
\hline Scale & Experience & $n$ & $X$ & $s d$ & $\begin{array}{l}\text { Treat- } \\
\text { ments }\end{array}$ & sS & df & MSS & F & $\mathrm{p}$ & $\eta^{2}$ \\
\hline \multirow{6}{*}{ TEA } & $1-5$ yrs. & 14 & 12.5 & 2.32 & G.Arası & 65.174 & 4 & 16.293 & 1.611 & .17 & .028 \\
\hline & 6-10 yrs. & 34 & 11.7 & 2.46 & G.IÇi & 2234.601 & 221 & 10.111 & & & \\
\hline & $11-15$ yrs. & 67 & 11.5 & 2.32 & Toplam & 2299.774 & 225 & & & & \\
\hline & $16-20$ yrs. & 71 & 11.9 & 2.79 & & & & & & & \\
\hline & $21+$ yrs. & 40 & 12.7 & 2.56 & & & & & & & \\
\hline & Total & 226 & 11.9 & 2.55 & & & & & & & \\
\hline \multirow{6}{*}{ TIA } & $1-5$ yrs. & 14 & 27.5 & 2.00 & G.Aras1 & .622 & 4 & .155 & .993 & .41 & .017 \\
\hline & 6-10 yrs. & 34 & 24.9 & 5.09 & G.İçi & 34.606 & 221 & .157 & & & \\
\hline & $11-15$ yrs. & 67 & 25.0 & 5.33 & Toplam & 35.227 & 225 & & & & \\
\hline & $16-20$ yrs. & 71 & 24.8 & 5.40 & & & & & & & \\
\hline & $21+$ yrs. & 40 & 24.7 & 6.23 & & & & & & & \\
\hline & Total & 226 & 25.0 & 5.35 & & & & & & & \\
\hline \multirow{6}{*}{ TPA } & $1-5$ yrs. & 14 & 40.2 & 2.82 & G.Arası & .385 & 4 & .096 & 1.080 & .36 & .019 \\
\hline & 6-10 yrs. & 34 & 36.8 & 6.49 & G.İçi & 19.687 & 221 & .089 & & & \\
\hline & $11-15$ yrs. & 67 & 36.7 & 6.49 & Toplam & 20.072 & 225 & & & & \\
\hline & $16-20$ yrs. & 71 & 36.9 & 6.68 & & & & & & & \\
\hline & $21+$ yrs. & 40 & 37.5 & 8.00 & & & & & & & \\
\hline & Total & 226 & 37.1 & 6.69 & & & & & & & \\
\hline
\end{tabular}




\section{Funding}

This study is an initial report of the ongoing research project supported by the The Scientific and Technological Research Council of Turkey.

\section{Kaynakça / References}

Altun, T. ve Vural, S. (2012). Bilim ve sanat merkezinde (Bilsem) görev yapan öğretmen ve yöneticilerin mesleki gelişim ve okul gelişimine yönelik görüşlerinin değerlendirilmesi. Elektronik Sosyal Bilimler Dergisi, 11 (42), 152-177

Bakioğlu, A. ve Salduz, E . (2014). Öğretmenlerin hesap verebilirliklerini öğrencilerin akademik başarısı açısından değerlendirmeleri. Marmara Üniversitesi Atatürk Eğitim Fakültesi Eğitim Bilimleri Dergisi, 40 (40), 13-29. http://dergipark.org.tr/maruaebd/issue/389/2703 adresinden erişilmiştir.

Boydak Ö. M. Polat, H. ve Şener, G. (2014). Sınıf öğretmenlerinin mesleki gelişim eğitimlerine ilişkin görüşlerinin belirlenmesi. Uşak Ün-iversitesi Sosyal Bilimler Dergisi, 20(20), 167-180.

Bülbül, M. (2011). Türk Milli Eğitim Sisteminde hesap verebilirlik. Doktora tezi, Gazi Üniversitesi Eğitim Bilimleri Enstitüsü, Ankara.

Ceylan, M. ve Özdemir, S. (2016). Türkiye Ve İngiltere'deki öğretmenlerin sürekli mesleki gelişime ilişkin görüşlerinin ve katılım durumlarının incelenmesi. Kırıkale Üniversitesi Sosyal Bilimler Dergisi, 6 (1), 397-417.

Cheng, Y. C. ve Tsui, K. T.. (1999). Multimodels of teacher effectiveness: Implications for research. Journal of Educational Research, 92 (3), 141-150.

Çiçekli, A. (2016). Kamu yönetiminde hesap verebilirlik ve BIMER'in hesap verebilir yönetime etkisi: Van sağllk hizmetleri örneği. Yüksek lisans tezi, Yüzüncü Yıl Üniversitesi, Van.

De Dreu, C. K., ve van Knippenberg, D. (2005). The possessive self as a barrier to conflict resolution: Effects of mere ownership, process accountability, and self-concept clarity on competitive cognitions and behavior. Journal of Personality and Social Psychology, 89, 345-357.

Ekici, G. (2014). Öğretmenin öğrencilerin akademik başarı ve başarısızlığından sorumluluk algısı konusunda görüşler: Biyoloji öğretmen adayları örneği. İlköğretim Online, 13(4), 1414-1448.

Erdağ, C. (2017). Accountability at schools: A study of path analysis. Educational Sciences: Theory and Practice, 17 (4), 1405-1432. 
Erdağ, C. ve Karadă̆, E. (2017). Öğretmenler ve okul müdürleri perspektifinden okul hesap verebilirliği politikaları. OPUS Uluslararası Toplum Araştırmalarn Dergisi, 7 (13), 459-496.

Erdağ, C., ve Karadă̆, E. (2018). Exploration of possible individual and institutional effects on school accountability pressures and teacher responses. Kuram ve Uygulamada Eğitim Yönetimi, 24(1), 93-142. DOI: 10.14527/kuey.2018.003

Erkoşar, N. (2013). Belediyelerde iyi yönetişim açısından hesap verebilirlik: Küçükçekmece Belediyesi, Yüksek lisans tezi, Fatih Üniversitesi, İstanbul.

Firestone, W.A. ve Shipps, D. (2005). How do leaders interpret conflicting accountabilities to improve student learning?. In (Firestone, W.A. and Riehl, C. Eds), A New Agenda for Research in Educational Leadership, (s. 81-100). Teachers College Press, New York, NY.

Folger, R., ve Cropanzano, R. (2001). Fairness theory: Justice as accountability. In( J. Greenberg, ve R. Cropanzano Eds.), Advances in organizational justice (p. 1-55). Stanford, CA: Stanford University Press.

Frink, D. D. ve Klimoski, R. J. (2004), Advancing accountability theory and practice: Introduction to the human resource management review special addition, Human Resource Management Review, 14, 1-17.

Frink, D. D., ve Ferris, G. R. (1998). Accountability, impression management, and goal setting in the performance evaluation process. Human Relations, 51(10), 1259-1283. doi:10.1177/001872679805101003

Frink, D.D. ve Klimoski, R.J. (1998). Toward a theory of accountability in organizations and human resource management. In (Ferris, G.R. Ed.), Research in Personnel and Human Resources Management, (s.1-15.)Vol. 16, Elsevier Science/JAI Press, Greenwich, CT,

Frink, D.D., Hall, A.T., Perryman, A.A., Ranft, A.L., Hochwarter, W.A., Ferris, G.R. ve Royle, M. T. (2008). Meso-level theory of accountability in organizations. Research in Personnel and Human Resources Management, 177-245.

Gökmenoğlu, T. Beyazova, G. ve Kılıçoğlu, A. (2015). Mesleki Gelişim: Öğrenen Olarak Öğretmen Eğitimcileri. İlköğretim Online, 14(2), 574-592.

Hall, A. T., ve Ferris, G. R. (2011). Accountability and extra-role behavior. Employee Responsibilities and Rights Journal, 23, 131-144. doi:10.1007/s10672010-9148-9 
Hall, A. T., Frink, D. D., Ferris, G. R., Hochwarter, W. A., Kacmar, C. J., ve Bowen, M. G. (2003). Accountability in human resources management. In (C. A. Schriesheim, ve L. Neider Eds.), New directions in human resource management (s. 29-63). Greenwich, CT: Information Age Publishing.

Hall, A. T. (2005). Accountability in organizations: An examination of antecedents and consequences. Doctoral Dissertation. The Florida State University, College of Business, USA.

Hall, A. T., Frink, D. D., ve Buckley, M. R. (2017). An accountability account: A review and synthesis of the theoretical and empirical research on felt accountability. Journal of Organizational Behavior, 38, 204-224.

Hochwarter, W.A., Perrewé, P.L., Hall, A.T. ve Ferris, G.R. (2005), Negative affectivity as a moderator of the form and magnitude of the relationship between felt accountability and job tension, Journal of Organizational Behavior, 26 (5) , 517-534.

Kantos, Z. (2010). İlköğretim okulu yönetici ve öğretmenlerinin görüşlerine göre kamu ve özel ilköğretim okullarn için bir hesap verebilirlik modeli. Yayınlanmamış doktora tezi, Ankara Üniversitesi, Ankara.

Kardaş, D.K. (2019). Putting bureaucratic accountability into a perspective in terms of academic achievement. Educational Assessment, Evaluation and Accountability, 31, 349-375. https://doi.org/10.1007/s11092-019-09304-9

Koçak, E, Turan, S. ve Aydoğdu, E . (2012). Öğretmenlerin yetki devri, otonomi ve hesap verebilirliklerine ilişkin görüşlerinin incelenmesi. Ĕ̆itim Ve Innsani Bilimler Dergisi: Teori Ve Uygulama, 5, 117-148.

Küçükaycan, D.(2018). Hesap verme sorumluluğu çerçevesinde belediyelerde performans raporlamanın performans denetim kriterleri açısından değerlendirilmesi,Yayınlanmamış doktora tezi, Eskişehir Osmangazi Üniversitesi, Eskişehir.

Lerner, J. S., ve Tetlock, P. E. (1999). Accounting for the effects of accountability. Psychological Bulletin, 125(2), 255-275.

Lerner, J., ve Tetlock, P. E. (2003). The impact of accountability on cognitive bias: Bridging individual, interpersonal, and institutional approaches to judgment and choice. In (S. Schneider ve J. Shanteau Eds), Emerging perspectives on judgment and decision making (s. 431-457). Cambridge: Cambridge University Press.

Levitt, R., Janta, B. ve Wegrich. K. (2008). Accountability of teachers: Literature review. Rand Europe. Retrived from https://dera.ioe.ac.uk/14020/1/1009_Accountability_of_teachers_Literature_review.pdf 
Mete, F. ve Gürsoy, Ü. (2014). Yabancı dil olarak Türkçe öğretiminde öğretmen yeterliklerine ilişkin görüşler. Hacettepe Üniversitesi Eğitim Fakültesi Dergisi, 28 (28-3), 343-356.

Mitchell, T. R. (1993). Leadership, values, and accountability. In (M. M. Chemers, ve R. Ayman Eds.), Leadership theory and research: Perspectives and directions ( s. 109-136). San Diego, CA: Academic Press.

Özcan, E. (2011). Türk kamu yönetiminde ve güvenlik hizmetlerinde hesap verebilirlik. Yüksek lisans tezi, Adnan Menderes Üniversitesi, Aydın.

Özen, F. (2011). Illköğretim okulu yönetici ve öğretmenlerinin görüşlerine göre okul geliştirme aracı olarak hesap verebilirlik. Yayınlanmamış doktora tezi. Ankara Üniversitesi, Ankara.

Roch, S. G., ve McNall, L. A. (2007). An investigation of factors influencing accountability and performance ratings. Journal of Psychology, 141, 499-523.

Rosenblatt, Z. (2017). Personal accountability in education: measure development and validation, Journal of Educational Administration, 55(1), 18-32, doi: 10.1108/JEA-10-2015-0093

Sabancl, A. (1999). İlkögretim okullarındaki ödül sisteminin öğretmenler ve müdür yardımcılar için önem derecesi, gereksinimleri karşılama ve iş doyumu să̆lama düzeyi. Yayınlanmamış Doktora Tezi, Hacettepe Üniversitesi Sosyal Bilimler Enstitüsü, Ankara.

Schlenker, B.R. ve Weigold, M.F. (1989), "Self-identification and accountability. In (Giacalone, R.A. and Rosenfeld, P. Eds), Impression Management in the Organization, Lawrence Erlbaum Associates, (s.21-43.), Hillsdale, NJ.

Scholten, L., van Knippenberg, D., Nijstad, B. A., ve De Dreu, C. K. (2007). Motivated information processing and group decision-making: Effects of process accountability on information processing and decision quality. Journal of Experimental Social Psychology, 43, 539-552.

Seyhani, M., Özder, H. ve Konedralı, G.(2009). An evaluation of the re-ward-punishment policies applied to trnc primary school teachers. Kuram Ve Uygulamada Eğitim Yönetimi, 57 (57), 109-131.

Soydan, T. (2012). Eğitim alanında performans değerlendirme sisteminin geçerliği üzerine yönetici ve öğretmen görüşlerine dayalı bir araştırma. Ege Ĕ̆itim Dergisi, 13 (1), 1-25.

Soydan, T.; Abalı, H. ve Kalsen, C. (2014). Eğitim alanında performans değerlendirme sistemine ilişkin okul yöneticilerinin görüşleri. Journal of Education and Future, 6, 91-114. 
Sumak, M. ve Roşan, Ş. (2015). Okul Temelli yönetimin ilköğretim okullarında uygulanabilirliğine ilişkin öğretmen ve yönetici tu-tumlarının incelenmesi: Gaziantep örneği Ahi Evran Üniversitesi Kırşehir Eğitim Fakültesi Dergisi, 7 (2), 317-334.

Tetlock, P. E. (1985). Accountability: The neglected social context of judgment and choice. In (L. L. Cummings, ve B. M. Staw Eds.), Research in organizational behavior (Vol. 7, s. 297-332). Greenwich, CT: JAI Press.

Too, D. R. (1989). Accountability in Hong Kong Secondary Education: The Attitudes of Principals and Vice-Principals in Anglican Schools, Master's Thesis, University Of Hong Kong, Hong Kong.

Türkoğlu, M.E. (2015). Öğretmen hesap verebilirliği: Özel bir okulda durum çalısması. Dissertation Thesis, Eskişehir Osmangazi Üniversitesi, Eskişehir Turkey. Retrieved from http://openaccess.ogu.edu.tr:8080/xmlui/bitsteam/handle/11684/363/10022484.pdf.pdf?sequence=1\&isAllowed=y

Uştu, H., Mentiş T. A. ve Sever, B.(2016). Öğretmenlerin mesleki gelişime yönelik algılarına ilişkin nitel bir araştırma. Elektronik Mesleki Gelişim Ve Araştırmalar Dergisi, 4 (1), 82-104.

Üstünkal, F. T. (2013). Eğitim örgütlerinde performans değerlendirmenin öğretmenler üzerindeki etkisi. Yayımlanmamış Yüksek Lisans Tezi, Yeditepe Üniversitesi Sosyal Bilimler Enstitüsü, İstanbul.

Yıldırım, K. ve Yenipınar, Ş . (2019). Okul yöneticilerine göre öğretimsel hesapverebilirlik olgusunun nitel analizi. Kastamonu Eğitim Dergisi, 27 (1), 151162. DOI: $10.24106 /$ kefdergi.2420

Yi, P. ve Kim, H.J. (2019). Exploring the relationship between external and internal accountability in education: A cross-country analysis with multi-level structural equation. International Journal of Educational Development, 65, 19. https://doi.org/10.1016/j.jijedudev.2018.12.007

\section{Kaynakça Bilgisi / Citation Information}

Erdağ, C. (2020). Öğretmenlerin bireysel hesap verebilirlik eğilimlerinin bireysel ve kurumsal bağlam özellikleri açısından karşılaştırılması. OPUS-Uluslararası Toplum Araştırmaları Dergisi, 15(21), 96124. DOI: 10.26466/opus.613111 